\title{
Growth and metabolic activities of cowpea seedlings exposed to artificial pond wastewater-treated soil
}

\author{
F. I. Achuba ${ }^{1} \cdot$ M. N. Oshiokpu ${ }^{1}$
}

Received: 1 December 2017 / Accepted: 11 April 2019 / Published online: 20 April 2019

(c) The Author(s) 2019

\begin{abstract}
Purpose The increase in demand for fish has necessitated the establishment of fish pond. The discharge of spent pond water pollutes the adjoining surroundings. The aim of this investigation was to determine the suitability of artificial pond wastewater (APWW) as source of manure for crop cultivation.

Method Cowpea seeds were planted in polybags containing soil treated with varied amount of artificial pond wastewater. Thereafter, growth and various metabolic properties of cowpea seedlings were determined using standard procedures.

Results Artificial pond wastewater treatment of soil increased significantly $(P<0.05)$ the growth parameters, content of biomolecules and activities of alpha amylase, starch phosphorylase and peroxidase when compared to the control. Exposure of the seedlings to APWW did not alter most oxidative stress markers compared to the control. In addition, APWW in soil significantly $(P<0.05)$ increases the levels of vitamin $C$ but had no alterations in the activities of succinate dehydrogenase $(\mathrm{SDH})$, lactate dehydrogenase (LDH) and sulphite oxidase (SO) of the cowpea seedlings compared to those of the controls. The activities of aldehyde oxidase (AO) and xanthine oxidase (XO) significantly $(P<0.05)$ increased compared with the control.

Conclusion The major effects of APWW on plants were stimulation of growth parameters, increase in concentration of macromolecules as well as increase in activities of starch-metabolizing enzymes, and peroxidase activity with no adverse effect on antioxidant, respiratory and drug-metabolizing enzymes, thus, suggesting that artificial pond wastewater has positive effect on cowpea seedlings and can act as organic fertilizer for cowpea cultivation.
\end{abstract}

Keywords Cowpea $\cdot$ Enzymes $\cdot$ Macromolecules $\cdot$ Pond $\cdot$ Wastewater

\section{Introduction}

The increase in world population and climate change factors has created new concerns about the ability of the world to feed itself in a sustainable manner (Cassman et al. 2003; Godfray et al. 2010). This is because the use of land for other purposes has resulted in sharp degradation of agricultural natural resources particularly, the soil (Eme et al. 2014). In addition, the hot and humid tropical environment is characterized by rapid weathering of soils resulting in large areas of ultisols and oxisols (Udoh and Iren 2016). The ultisols and oxisols regions have poor chemical properties and this adversely affects agriculture in these regions (Golabi et al.

F. I. Achuba

achubabch@yahoo.com

1 Department of Biochemistry, Delta State University, PMB 1, Abraka, Nigeria
2004; Udoh and Iren 2016). The soils of these regions have low organic matter content due to heavy rainfall $(3000 \mathrm{~mm})$ and high temperature $\left(28-33^{\circ} \mathrm{C}\right)$ (UNDP 2006). The high temperature and heavy rainfall cause rapid organic matter decomposition, which also acidify the soil due to the release of hydrogen ions (Golabi et al. 2004).

The conventional soil improvement technologies employed by farmers are the use of inorganic fertilizers, crop rotation, bush fallowing and the use of agro-chemicals (Udoh and Iren 2016). However, factors such as soil degradation due to intensive cultivation and reduction in fallow periods occasioned by population pressure and industrialization alongside monocultural practice by most farmers in Nigeria have made crop rotation and bush fallowing almost impracticable and inadequate (Udoh et al. 2016). This coupled with factors such as the portability, high nutrient concentration, nutrient stability and high crop yield of inorganic fertilizers led to overdependence on inorganic fertilizers as 
both soil and crop improvement method (Udoh and Iren 2016, Udoh et al. 2016). However, inorganic fertilizers cannot correct excessive degradations of soils by a high rainfall regime. In addition, the high cost of inorganic fertilizers makes them unaffordable to poor farmers (Udoh and Iren 2016). More so, the continuous use of chemical fertilizers has been reported to result in nutrient imbalance in the soil, hence the need for organic manures for crop production (Maheshbabu et al. 2008; Adeniyan et al. 2011). Besides, the first step in any farming practice in tropical environment is the use of organic manure. This is because organic matter is an essential part of soil physical properties, aggregation and moisture-holding capacity. This provides a platform for good productivity. Therefore, soil and crop improvement method that is able to preserve satisfactory physical and chemical conditions of the soil must be employed (Golabi et al. 2004; Argaw 2017).

A good number of researches have shown soils amended with animal and plant manures improved soil conditions and crop yields (Iren et al. 2011; John et al. 2013; Udoh et al. 2016; Khaliq et al. 2017). Ayeni and Adetunji (2010) reported that organic fertilizers positively impacted soil nutrient, soil structure, base saturation and bulk density. Moreover, organic manures are rich in organic matter and are a good substrate for the growth of soil microorganisms and they positively affect nutritional balance and the physical properties of soil (Maheshbabu et al. 2008). Soils treated with organic manures have been reported to significantly improve soil productivity and the yield of maize (John et al. 2013). Iren et al. (2015) reported that organic manures improved the sustained production of water leaf.

Water pollution from discharging wastewater of fish farms has become a concern worldwide (Ghate et al. 1993; Pulatsu et al. 2004; Fadaeifard et al. 2012; Omofunmi et al. 2016). Although the constituents of fish pond wastewater depend on the proximate composition of the feed used and its stability, as well as fish-feeding methods employed, a typical wastewater from fish pond normally contains fish metabolic products, fish feces and unused nutrients residue (Fadaeifard et al. 2012). Proper management of fish feeding, wastewater treatment and proper wastewater disposal have been the focus of aquaculture industry as a way of reducing pollutions by fish pond wastewater (Fadaeifard et al. 2012). In some parts of Asia, domestic wastewater was traditionally used as fertilizer in agriculture or as soil conditioner (Naddafi et al. 2005). The report of FAO (2014) has also shown that the residue that settles in fish ponds as silt are rich in nutrient and, therefore, wastewater from fish pond is a useful organic fertilizer for crop cultivation. In a like manner, fish pond effluent had been applied in the cultivation of crops such as French beans (Meso et al. 2007), amaranthus (Ojobor and Tobih 2015), pineapple (Udoh et al. 2016) and garden egg (Udoh et al. 2016). Literature search indicates dearth of information in this regard. Therefore, the aim of this study was to establish the effect of artificial pond wastewater on some aspects of growth and metabolism of cowpea seedlings.

\section{Materials and methods}

The artificial pond wastewater was collected from concrete pond in Obiaruku, Nigeria. The physical and chemical characteristics of the wastewater are shown in Table 1. The soil sample used and its physicochemical properties were previously described (Achuba and Okoh 2014).

\section{Experimental design}

One thousand six hundred grams of soil was added to each bag and divided into nine groups; the groups were treated with $10 \mathrm{ml}, 20 \mathrm{ml}, 30 \mathrm{ml}, 40 \mathrm{ml}, 50 \mathrm{ml}, 60 \mathrm{ml}, 80 \mathrm{ml}$ and $100 \mathrm{ml}$, and $0.00(\mathrm{v} / \mathrm{w})$ of artificial pond wastewater. The required volume of tap water was added to the treatments to make each treated groups have equal amount of water $(100 \mathrm{ml})$. Five seeds of the $V$. unguiculata were sown in each test bag to an approximate depth of $2 \mathrm{~cm}$ and kept under

Table 1 Properties and composition of APWW used

\begin{tabular}{ll}
\hline Parameters & Values \\
\hline $\mathrm{pH}$ & $6.98 \pm 0.5$ \\
Conductivity $\left.(\mathrm{dS} \mathrm{m})^{-1}\right)$ & $126 \pm 35.4$ \\
Turbidity $(\mathrm{NTU})$ & $136.7 \pm 21.6$ \\
$\mathrm{TDS}\left(\mathrm{mgL}^{-1}\right)$ & $374.6 \pm 16.3$ \\
$\mathrm{TSS}\left(\mathrm{mgL}^{-1}\right)$ & $266.3 \pm 35.6$ \\
$\mathrm{COD}\left(\mathrm{mgL}^{-1}\right)$ & $346.5 \pm 28.6$ \\
BOD $\left(\mathrm{mgL}^{-1}\right)$ & $3.13 \pm 0.6$ \\
DO $\left(\mathrm{mgL}^{-1}\right)$ & $10.8 \pm 1.4$ \\
Acidity $\left(\mathrm{mgL}^{-1}\right)$ & $141.2 \pm 11.6$ \\
Alkalinity $\left(\mathrm{mgL}^{-1}\right)$ & $53.6 \pm 5.7$ \\
Hardness $\left(\mathrm{mgL}^{-1}\right)$ & $1.02 \pm 0.01$ \\
Mg $\left(\mathrm{mgL}^{-1}\right)$ & $1.33 \pm 0.02$ \\
Ca $\left(\mathrm{mgL}^{-1}\right)$ & $36.3 \pm 1.6$ \\
Chloride $\left(\mathrm{mgL}^{-1}\right)$ & $11.3 \pm 1.20$ \\
Sulfate $\left(\mathrm{mgL}^{-1}\right)$ & $2.06 \pm 0.56$ \\
Phosphate $\left(\mathrm{mgL}^{-1}\right)$ & $2.01 \pm 0.02$ \\
Nitrate $\left(\mathrm{mgL}^{-1}\right)$ & $3.02 \pm 0.01$ \\
Copper $\left(\mathrm{mgL}^{-1}\right)$ & $0.03 \pm 0.001$ \\
Zinc $\left(\mathrm{mgL}^{-1}\right)$ & $0.04 \pm 0.002$ \\
Lead (mgL & $0.01 \pm 0.001$ \\
Cadmium & $\mathrm{ND}$ \\
\hline
\end{tabular}

TDS Total dissolved solid, TSS total suspended solid, COD chemical oxygen demand, $B O D$ biological oxygen demand, $D O$ dissolved oxygen, $N D$ not detected 
partial shade. During the experiment, water $\left(80 \mathrm{~cm}^{3}\right)$ was added daily to keep the soil moist.

\section{Determination of morphological parameters}

The stem lengths of the seedlings were measured 12 days after planting. The stem length was measured from the soil level to the terminal bud. Leaf area of the seedlings was determined using a ruler and its value converted by multiplying with a correction factor. The uprooted seedlings were carefully rinsed with water and air dried. Fresh weight was determined from specimens of cowpea seedlings using the Setra BL-40s electronic balance.

\section{Determination of biochemical parameters}

The concentrations of total carbohydrate, reducing sugar, amino acid, total protein and chlorophyll were estimated as previously described (Achuba 2006).

\section{Determination of total sugar content, glucose, amino acid and total protein}

Leaf homogenate needed for total sugar, glucose, amino acid and protein determinations was prepared as previously described (Achuba 2006), and the sugar and protein were determined using the methods of Tietz (1982) and Lowry et al. (1951), respectively. While total free amino acid was determined by ninhydrin method after deproteination with $5 \%$ trichloroacetic acid (TCA). Glucose was determined by the method of Trinder (1969).

\section{Determination of photosynthetic pigments (chlorophyll and $\beta$-carotene)}

The leaf $(1.0 \mathrm{~g})$ was homogenized in $96 \%$ methanol with a mortar and pestle, and the resultant homogenate centrifuged at $2500 \mathrm{rpm}$ for $10 \mathrm{~min}$. The supernatant obtained was diluted and used for the determinations of chlorophylls and carotene. Chlorophyll was determined as stated by Lichtenthaler (1987) and carotenoid was determined by taking the absorbance of the supernatant at $662 \mathrm{~nm}, 646 \mathrm{~nm}$ and $470 \mathrm{~nm}$, and the concentration determined by Duxbury and Yentsch (1956).

\section{Determinations of starch-metabolizing enzymes and peroxidase activities}

Alpha-amylase activity was assayed using the method of Gupta et al. (2003) and the activity calculated using the formula of Xiao et al. (2006). Starch phosphorylase activity was assayed using the method of Singh and Steinnes (1976).
Peroxidase activity was assayed as reported in Rani et al. (2004).

\section{Determinations of antioxidant parameters and drug-metabolizing enzymes}

Oxidative stress parameters were determined as stated in Rani et al. (2004). Vitamin C was determined as described in Achuba (2008). Succinate dehydrogenase and lactate dehydrogenase activities were carried out using the methods of Sajan et al. (1995) and Kaiglova et al. (2001), respectively. The methods of Macleod et al. (1961), Johns (1967) and Stirpe and Della Corte (1969) were adopted to determine sulphite oxidase, aldehyde oxidase and xanthine oxidase activities, respectively.

\section{Statistical analysis of data}

Analysis of variance (ANOVA) and post hoc Fisher's test for multiple comparisons were performed on the data generated with statistical package for social science (SPSS), version 21 , and level of significance was set at $P$ values $<0.05$.

\section{Results and discussion}

The progressive increase in world population alongside the ever decreasing available agricultural lands and unpredictable negative impact of climate change poses a major threat to global food security (Cassman et al. 2003; Godfray et al. 2010; Eme et al. 2014; Udoh et al. 2016). This has resulted in the search for measures that could curtail impending food shortages and world hunger both by governmental and intergovernmental agencies (FAO 2014; Udoh and Iren 2016).

One among other several methods that have the potential of boosting the ability of the world to feed itself amidst the progressive increase in world population and the decreasing available agricultural lands is increasing the yield and productive capacity of the available agricultural lands (Udoh and Iren 2016). Soil and crop improvement method that is able to preserve satisfactory physical and chemical conditions of the soil is essential for increased productivity to meet global food demand (Golabi et al. 2004; Hussain et al. 2017; Radin et al. 2018). Artificial pond wastewater is organic manure (Udoh and Iren 2016). Organic manures are rich in organic matter and microorganisms, which can enhance the biochemical characteristics of soils, as well as their fertility (Kajimura et al. 2004; Fadaeifard et al. 2012; Benabderrahim et al. 2017). Several researchers have reported improved soil conditions and crop yields by treatment with organic manures (Mhamdi et al. 2010; Bray et al. 2000). 
Domestic wastewater was traditionally used as a fertilizer in agriculture or as soil conditioner, and pond effluent has been used to improve the growth rate and quality of crops (Wood et al. 2001; Naddafi et al. 2005; Ojobor and Tobih 2015). This present study investigated the effects of artificial pond wastewater (APWW)-treated soil on the growth and biochemical indices of cowpea seedlings. Artificial pond wastewater-treated soil stimulated growth parameters (leaf length, leaf area and fresh weight) and macromolecules of the cowpea seedlings relative to the control, most especially at higher volume of the wastewater-treated soil (Figs. 1 and 2).

This is corroborated by the findings of some researchers who reported improved growth and yield as well as increased protein and chlorophyll contents of plants grown in soils amended with organic manures (Abo-Shady et al. 2017). Udoh and Iren (2016)reported that soils treated with fish pond wastewater increased soil organic matter, nitrogen, phosphorus, calcium and bulk density than organic manure (pig manure, poultry manure) and inorganic fertilizer (NPK). The improved levels of these biomolecules in the experimental seedlings may be predicated on the high content of organic matter, phosphorus, nitrogen and calcium. Phosphorus is important for chlorophyll formation (Nelson and Cox 2005), which is needed for the formation of carbohydrates via photosynthesis, and the byproducts of carbohydrates used to produce proteins and amino acids (Nelson and Cox 2005; Achuba 2006).

Alpha amylase and starch phosphorylase are two enzymes that are important in starch degradation. Starch metabolism which involves degradation and synthesis is important for seed germination and plant growth (Nelson and Cox 2005; Achuba 2006). Treatment of soil with APWW resulted in increase in the activities of alpha amylase, starch phosphorylase and peroxidase in cowpea seedlings. The increase in the activities of alpha amylase and starch phosphorylase was significant $(P<0.05)$ for all the APWWtreated groups compared with the control. However, the increase in the activity of peroxidase was only significant for cowpea seedlings grown in soil treated with $80 \mathrm{ml}$ of APWW (Fig. 3).

This could mean better growth of these seedlings as more energy will be available for growth through efficient starch mobilization during early seedling development. Also, the increase in peroxidase activity observed in this study upon the application of artificial pond wastewater is not far fetched as artificial pond wastewater is rich in nutrient and organic matter that stimulate plant growth (Kajimura et al. 2004; Fadaeifard et al. 2012; FAO 2014; Udoh and Iren 2016). This may be predicated on the fact that peroxidase is involved in cell wall biosynthesis, whose increase in activity leads to concomitant plant growth (Chanda and Singh 1997; Pandey et al. 2017).

Malondialdehyde (MDA) is an important byproduct of lipid peroxidation and, therefore, it is a very sensitive indicator of lipid peroxidation (Bhattacharjee 2014). Increased levels of MDA and thus increased peroxidation of membrane lipids cause cellular damage (Nwaogu and Onyeze 2014). Superoxide dismutase (SOD), catalase (CAT) and vitamin $\mathrm{C}$ are important enzymes and non-enzyme antioxidant that scavenge the noxious superoxide ion (Mazid et al. 2011; Zhang 2013). This underscored the importance of these parameters. There was no significant $(P<0.05)$ increase in total SOD activity and MDA levels in cowpea seedlings grown in soil treated with APWW compared with the control. However, $\mathrm{Cu} / \mathrm{ZnSOD}, \mathrm{MnSOD}$ and catalase activities significantly $(P<0.05)$ increased in cowpea seedlings grown in soil treated with APWW compared to the control.
Fig. 1 The morphological characteristics of cowpea seedlings grown in soils treated with artificial pond wastewater and the control. Results are expressed as mean of four determinations. a: not different significantly $(P<0.05)$ relative to control; b: different significantly $(P<0.05)$ relative to control
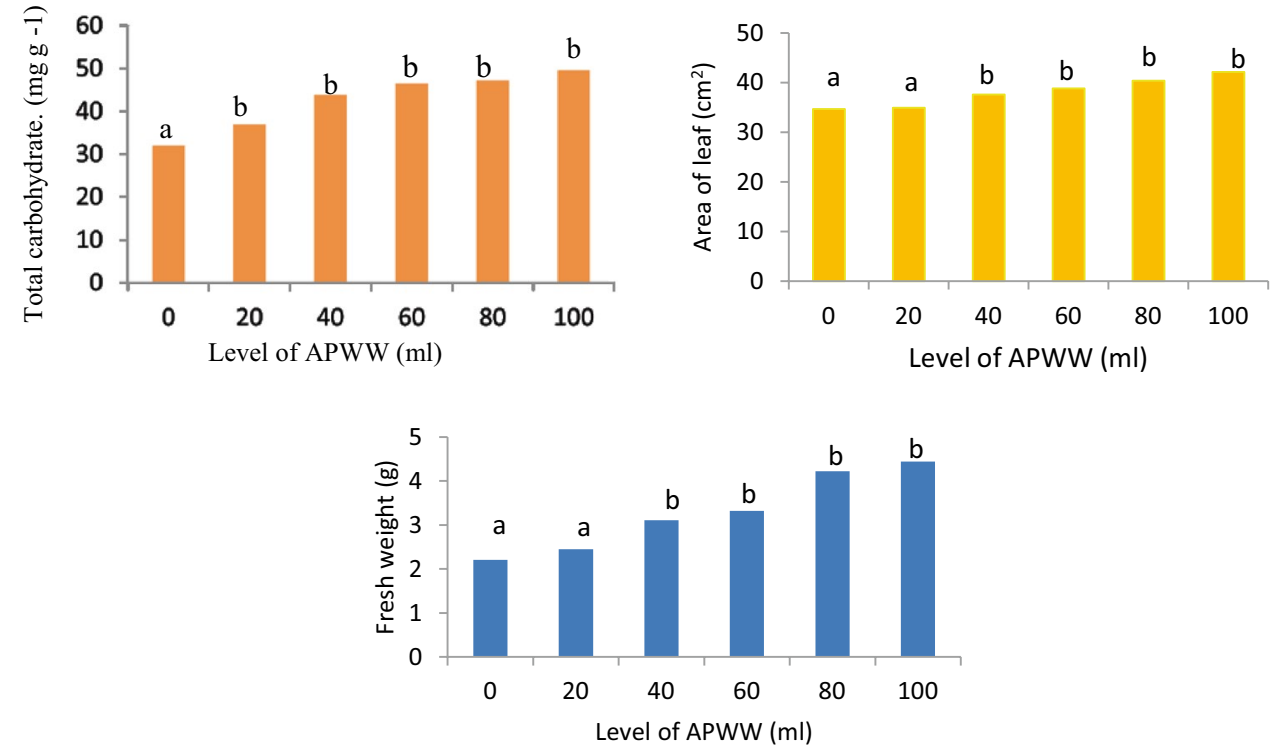
Fig. 2 The content of macromolecules of cowpea seedlings grown in soils treated with artificial pond wastewater and the control. Results are expressed as mean of four determinations. a: not different significantly $(P<0.05)$ relative to control; b: different significantly $(P<0.05)$ relative to control
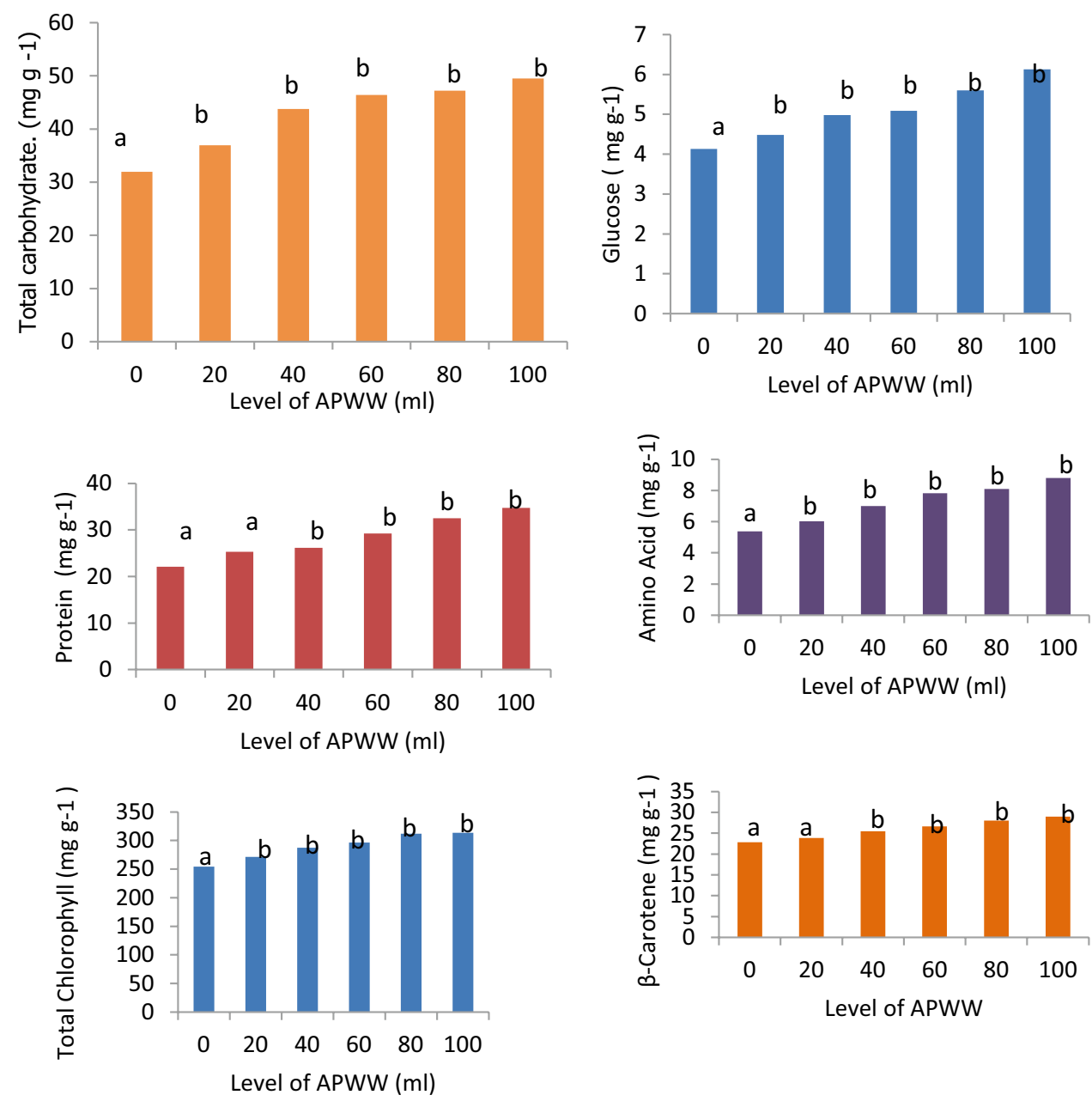

Fig. 3 The activities of some metabolic enzymes of cowpea seedlings grown in soils treated with artificial pond wastewater and the control. Results are expressed as mean of four determinations. a: not different significantly $(P<0.05)$ relative to control; b: different significantly $(P<0.05)$ relative to control
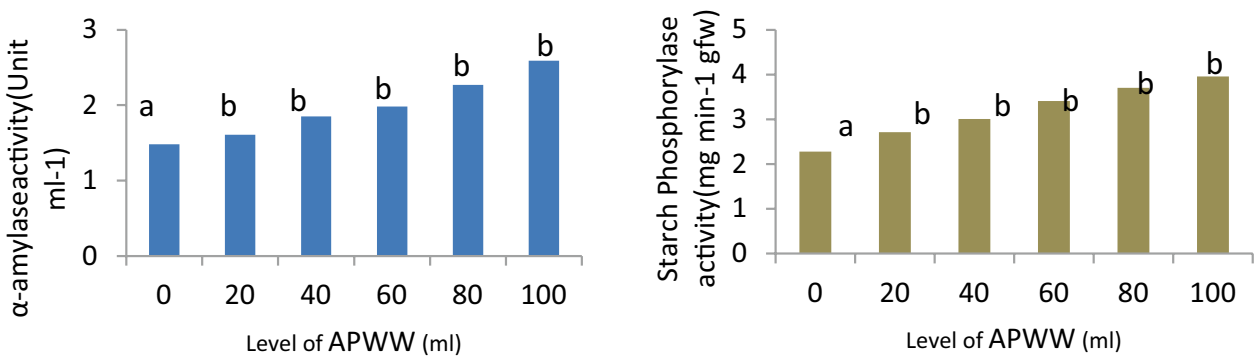

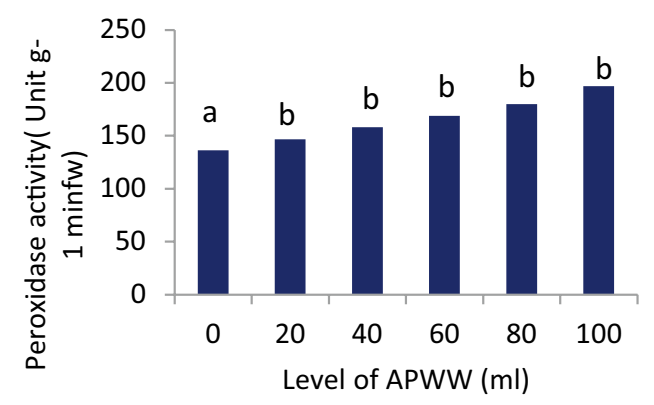


Moreover, the levels of vitamin C significantly increased in cowpea seedlings grown on APWW-treated soil compared to the control (Fig. 4).

This may imply a better ability of these plants to handle oxidative stress as both catalase and vitamin $\mathrm{C}$ in addition to the SODs act to protect plant cell from oxidative damage (Gaetani et al. 1996; Nelson and Cox 2005). This suggests that the treatment of soils with APWW did not stimulate oxidative stress in cowpea seedlings. Biofertilizerstimulated increase in yield and SOD activity in plants has been reported (AlAbdallah et al. 2017; El-Batanony 2017; Moustafad et al. 2017). The increase in these SODs may be APWW-induced activity to protect the seedlings from endogenous superoxide ion (Achuba 2014).

The results indicated no significant increase in the activities of succinate dehydrogenase (SDH), lactate dehydrogenase (LDH) and sulphite oxidase (SO) of cowpea seedlings grown in APWW-treated soil compared to that of the controls. Conversely, the activities of aldehyde oxidase (AO) significantly increased at all levels of APWW compared to the control while significant increase in the activities of xanthine oxidase (XO) was only recorded at $60 \mathrm{ml}, 80 \mathrm{ml}$ and $100 \mathrm{ml}$ of APWW compared with the control (Fig. 5).
The similarity in the activities of succinate dehydrogenase and lactate dehydrogenase activity in APWW-exposed plant and the control indicates that APWW has no adverse effect on energy metabolism. This is because succinate dehydrogenase activity is a measure of aerobic respiration while lactate dehydrogenase activity measures anaerobic respiration (Achuba 2014). In the same vein, the activities of xenobiotic metabolizing enzymes were not affected by the APWW. These enzymes have been reported to be part of the detoxifying process in plant exposed to polluted environment (Achuba and Okunbor 2015, Asagba et al. 2017).

\section{Conclusion}

The major effects of APWW on plants were stimulation of growth parameters, increase in concentration of macromolecules as well as increase in activities of starch-metabolizing enzymes, peroxidase activity with no adverse effect on antioxidant, respiratory and drug-metabolizing enzymes. The positive alterations of these biochemical parameters indicated that APWW was not injurious to exposed seedlings. These observations suggested that artificial pond wastewater
Fig. 4 The antioxidant status of cowpea seedlings grown in soils treated with artificial pond wastewater and the control. Results are expressed as mean of four determinations. a: Not different significantly $(P<0.05)$ relative to control; b: different significantly $(P<0.05)$ relative to control
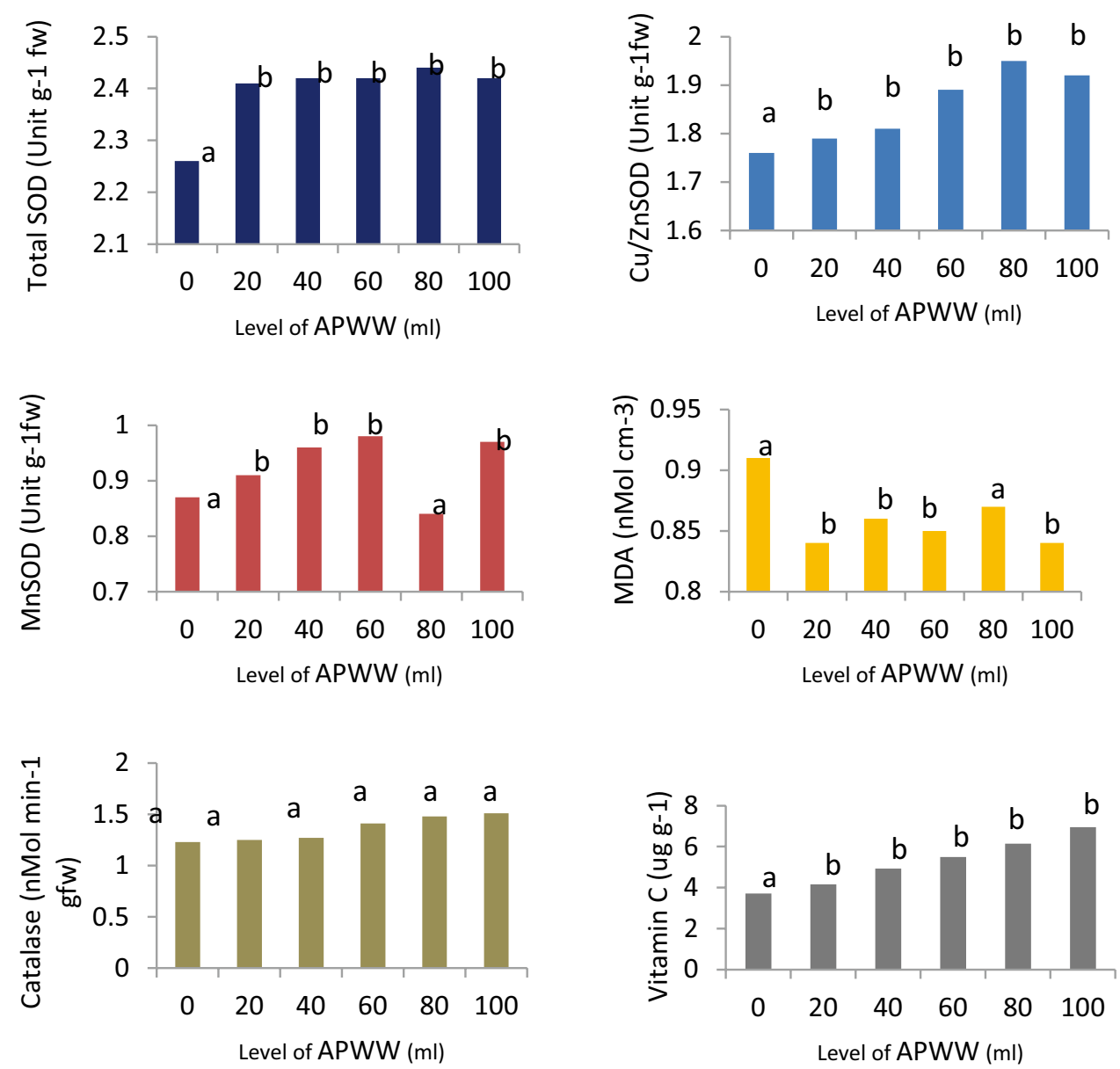
Fig. 5 The activities of some oxidative and respiratory enzymes of cowpea seedlings grown in soils treated with artificial pond wastewater and the control. Results are expressed as mean of four determinations. a: Not different significantly $(P<0.05)$ relative to control; b: different significantly $(P<0.05)$ relative to control
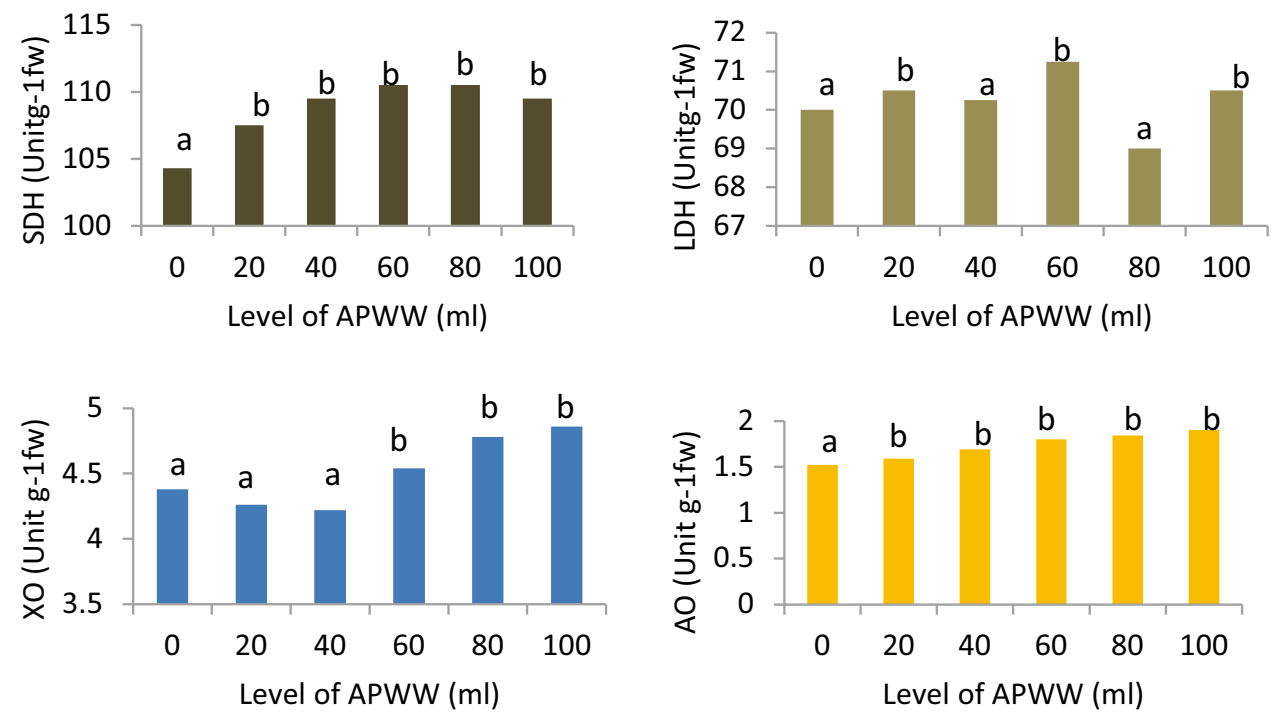

has a positive effect on cowpea seedlings and can act as organic fertilizer for cowpea cultivation.

Open Access This article is distributed under the terms of the Creative Commons Attribution 4.0 International License (http://creativeco mmons.org/licenses/by/4.0/), which permits unrestricted use, distribution, and reproduction in any medium, provided you give appropriate credit to the original author(s) and the source, provide a link to the Creative Commons license, and indicate if changes were made.

\section{References}

Abo-Shady AM, Khairi HM, Abomhra A, Elsobary M, Essa D (2017) Influence of algal bio- treated industrial wastewater of two companies at Kafr El -Zayat city on some growth parameters of Vicia faba. Egypt J ExpBiol (Bot) 13(2):209-217. https://doi. org/10.5455/egyjebb.20170622125025

Achuba FI (2006) The effect of sub lethal concentrations of crude oil on the growth and metabolism of cowpea (Vigna unguiculata) seedlings. Environmentalist 26:17-20. https://doi.org/10.1007/ s10669-006-5354-2

Achuba FI (2008) African land snail Achatina marginatus, as bioindicator of environmental pollution. North- Western J Zool 4(1):1-5

Achuba FI (2014) Petroleum products in soil mediated oxidative stress in cowpea (Vigna unguiculata) and Maize (Zea mays) seedlings. Open J Soil Sci 4:417-435. https://doi.org/10.4236/ ojss.2014.412042

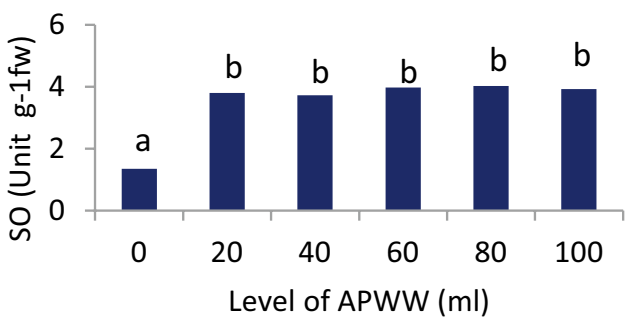

Achuba FI, Okoh PN (2014) Effect of petroleum products on soil catalase and dehydrogenase activities. Open J Soil Sci 4:399-406. https://doi.org/10.4236/ojss.2014.412040

Achuba FI, Okunbor G (2015) Abattoir wastewater attenuates kerosene toxicity on cowpea (Vigna unguiculuta) seedlings. Biokemistri 27(4):159-162

Adeniyan ON, Ojo AO, Akinbode A, Adediran JA (2011) Comparative study of different organic manures and NPK fertilizer for improvement of soil chemical properties and dry matter yield of maize in two different soils. J Soil Sci Environ Mgt 2(1):9-13

AlAbdallah NM, Basalah MO, Roushdy SS (2017) The promotive effect of algal biofertilizers on growth and some metabolic activities of Vigna unguiculata L. under salt stress conditions. Egypt J Exp Biol (Bot.) 13(2):187-195. https://doi.org/10.5455/egyje bb. 20170616083640

Argaw A (2017) Organic and inorganic fertilizer application enhances the effect of Bradyrhizobium on nodulation and yield of peanut (Arachis Hypogea L.) in nutrient depleted and sandy soils of Ethiopia. Int J Recycl Org Waste Agricult 6:289-299. https://doi. org/10.1007/s40093-017-0176-4

Asagba SO, Ezedom T, Kadiri H (2017) Influence of farmyard manure on some morphological and biochemical parameters of cowpea (Vigna unguiculata) seedling grown in cadmium-treated soil. Environ Sci Pollut Res Int 24(30):23735-23743. https://doi. org/10.1007/s11356-017-9988-Z

Ayeni LS, Adetunji MT (2010) Integrated application of poultry manure and mineral fertilizer on soil chemical properties, nutrient uptake, yield and growth components of maize. Nat Sci 8(1):60-67

Benabderrahim MA, Elfalleh W, Belayad H, Haddad M (2017) Effect of date palm waste compost on forage alfalfa growth, yield, seed 
yield and minerals uptake. Int J Recycl Org Waste Agric. https:// doi.org/10.1007/s40093-017-0182-6

Bhattacharjee S (2014) Membrane lipid peroxidation and its conflict of interest: the two faces of oxidative stress. Curr Sci 107(11):1811-1823

Bray EA, Bailey-Serres J, Weretilnyk E (2000) Responses to abiotic stresses. In: Buchannan B, Gruissem W, Jones R (eds) Biochemistry and molecular biology of plants. American Society of Plant Biology, Rockville, pp 1158-1203

Cassman KG, Dobermann A, Walters DT, Yang H (2003) Meeting cereal demand while protecting natural resources and improving environmental quality. Ann Rev Environ Resour 28:315-358

Chanda SV, Singh VD (1997) Changes in peroxidase and IAA oxidase activities during wheat grain development. Plant Physiol Biochem 35:245-250

Duxbury AC, Yentsch CS (1956) Plankton pigment nomographs. J Mar Res 15(4):92-101

El-Batanony NH (2017) Synergetic effect of combination of Gracilaria dendroides extract and Azospirillum lipoferaum on growth and yield of sunflower (Helianthus annuus L.). Egypt J Exp Biol (Bot) 13(3):31-40. https://doi.org/10.5455/egyjebb.20170 207082848

Eme OI, Onyishi AO, Uche OA, Uche IB (2014) Food insecurity in Nigeria: a thematic exposition Arabian. J Bus Mgt Rev 4(1):1-14 (OMAN Chapter)

Fadaeifard F, Raissy M, Faghani M, Majlesi A, Farahani GN (2012) Evaluation of physicochemical parameters of wastewater from rainbow trout fish farms and their impacts on water quality of Koohrang stream-Iran. Intl J Fish Acqua 4(8):170-177

FAO (Food and Agriculture Organization of the United Nation) (2014) The state of world fisheries and aquaculture. Opportunities and Challenges, FAO, Rome, p 243

Gaetani G, Ferraris A, Rolfo M, Mangerini R, Arena S, Kirkman H (1996) Predominant role of catalase in the disposal of hydrogen peroxide within human erythrocytes. Blood 87(4):1595-1599

Ghate SR, Burtle GJ, Gascho GJ (1993) Reuse of water from catfish ponds. In: Proceedings of the 1993 Georgia Water Resources Conference, held April 20 and 21, 1993, at The University of Georgia, Hatcher KI (ed) Institute of Natural Resources, The University of Georgia, Athens, Georgia, pp 391-393

Godfray HCJ, Beddington JR, Crute IR, Haddad L, Lawrence D, Muir JF, Pretty J, Robinson S, Thomas SM, Toulmi C (2010) Food security: the challenge of feeding 9 billion people. Science 327(5967):812-818. https://doi.org/10.1126/science.1185383

Golabi MH, Denney MJ, Iyekar C (2004) Use of composted organic wastes as alternative to synthetic fertilizers for enhancing crop productivity and agricultural sustainability on the tropical island of Guam. In: ISCO 2004-13th International Soil Conservation Organization Conference-Brisbane, July 2004, pp 218-234

Gupta RP, Gigras H, Mohapatra GV, Kumar A, Chauhan B (2003) Microbial amylases: a biotechnological perspective. Proc Biochem 38:1599-1616

Hussain N, Abbasi T, Abbasi SA (2017) Enhancement in the productivity of ladies finger (Abelmoschus esculentus) with concomitant pest control by the vermicompost of the weed salvinia (Salviniamolesta, Mitchell). Int J Recycl Org Waste Agric 6:335-343. https ://doi.org/10.1007/s40093-017-0181-7

Iren OB, Asawalam DO, Osodeke VE, John NM (2011) Comparative effects of animal manures and urea fertilizer on soil properties in a rainforest ultisol. J Agric Res Pollut 6(2):51-56

Iren OB, Akpan JF, Ediene VF, Asanga EE (2015) Influence of cassava peels and poultry manure-based compost on soil properties, growth and yield of waterleaf (Talinum triangulare Jacq) in an ultisol of south-eastern Nigeria. J Soil Sci Environ Mgt 6(7):187-194
John NM, Uwah DF, Iren OB, Akpan JF (2013) Changes in maize (Zea mays L.). Performance and nutrients content with the application of poultry manure, municipal solid waste and ash Composts. J Agric Sci 5(3):270-277

Johns DG (1967) Human liver aldehyde oxidase: differential inhibition of oxidation of charged and uncharged substrates. J Clin Invest 46:1492-1505

Kaiglova A, Reichrtova E, Aclamcakova A, Wsolora L (2001) Lactate dehydrogenase activity in human placenta following exposure to environmental pollutants. Physiol Res 50:525-528

Kajimura M, Croke SJ, Glover C, Wood CM (2004) Dogmas and controversies in the handling of nitrogenous wastes: the effect of feeding and fasting on the excretion of ammonia, urea and other nitrogenous waste products in rainbow trout. J Exper Biol 207:1993-2002

Khaliq SJA, Al-Busaidi A, Ahmed M, Al- Wardy M, Agrama H, Choudri BS (2017) The effect of municipal sewage sludge on the quality of soil and crops. Int J Recycl Org Waste Agric 6:289-299. https://doi.org/10.1007/s40093-017-0176-4

Lichtenthaler HK (1987) Chlorophylls and carotenoids: pigments of photosynthetic biomembranes. In: Packer L, Douce R (eds) Methods in enzymology. Academic Press, New York, pp 350-382

Lowry OH, Rosebrough NJ, Farr AL, Randal RJ (1951) Protein measurement with the folin phenol reagent. Biol Chem 193:265-275

Macleod RM, Farkas W, Fridovich I, Handler I (1961) Purification and properties of hepatic sulphite oxidase. J Biol Chem 236:1841-1846

Maheshbabu HM, Hunje R, Biradar NK, Babalad HB (2008) Effect of organic manures on plant growth, seed yield and quality of soybean. Karnataka J Agric Sci 21(2):219-221

Mazid M, Khan TA, Khan ZH, Quddusi S, Mohammad F (2011) Occurrence, biosynthesis and potentialities of ascorbic acid in plants. Intl J Plant Animal Environ Sci 1(2):167-184

Meso BM, Wood WC, Karanja NK, Veverica KL, Woomer PL, Kinyali SM (2007) Effect of Fish Pond Effluents Irrigation on French Beans in Central Kenya. Comm Soil Sci Plant Anal 35(78):1021-1031. https://doi.org/10.1081/CSS-120030578

Mhamdi A, Queval G, Chaouch S, Van Breusegem F, Noctor G (2010) Catalase function in plants: a focus on Arabidopsis mutants as stress-mimic models. J Exp Bot 61(15):4197-4220. https://doi. org/10.1093/jxb/erq282

Moustafad YMM, Haddad SA, Ahmed MMR (2017) Influence of biofertilization with the red yeast (Phaffia rhodozyma) on growth, yield and inulin content of jerusalem artichoke. Egypt J Exp. Biol (Bot.) 13(1):111-117. https://doi.org/10.5455/egyjebb.20170 313105731

Naddafi K, Jaafarzadeh N, Mokhtari M, Zakizadeh B, Sakian MR (2005) Effects of wastewater stabilization pond effluent on agricultural crops. Intl J Environ Sci Technol 1(4):273-277

Nelson DL, Cox MM (2005) Lehninger principles of biochemistry, 4th edn. WH Freeman \& Co, New York

Nwaogu LA, Onyeze GO (2014) Effect of chronic exposure to petroleum hydrocarbon pollution on oxidative stress parameters and histology of liver tissues of native fowl (Gallus domestics). Intl J Biochem Res Rev 4(3):233-242

Ojobor SA, Tobih FO (2015) Effects of fish pond effluent and inorganic fertilizer on amaranthus yield and soil chemical properties in Asaba, Delta State, Nigeria. J Agric Environ Sci 4(1):237-244. https://doi.org/10.15640/jaes.v4n1a29

Omofunmi OE, Adewumi JK, Adisa AF, Alegbeleye SO (2016) To assess the impact catfish farm effluents on water quality of majidun stream, south-west, Nigeria. J Environ Sci Toxicol Food Technol 10:28-35

Pandey VP, Awasthi M, Singh S, Tiwari S, Dwivedi UN (2017) A comprehensive review on function and application of plant 
peroxidases. Biochem Anal Biochem 6:308. https://doi. org/10.4172/2161-1009.1000308

Pulatsu S, Rad F, Köksal G, Aydın F, Benli ACK, Topçu A (2004) The impact of rainbow trout farm effluents on water quality of Karasu Stream, Turkey. Turkish J Fisher Aquat Sci 4:09-15

Radin R, Bakar RA, Ishak CF, Ahmad SH, Tsong LC (2018) Biocharcompost mixture as amendment for improvement of polybaggrowing media and oil palm seedlings at main nursery stage. Int $\mathbf{J}$ Recycl Org Waste Agricult. 7(1):11-23. https://doi.org/10.1007/ s40093-017-0185-3

Rani P, Meena UK, Karthikeyan J (2004) Evaluation of antioxidant properties of berries. Indian J Clin Biochem 19(2):103-110. https ://doi.org/10.1007/BF02894266

Sajan MP, Satav JG, Bhattacharya RKC (1995) Activity of some respiratory enzymes and cytochrome contents in rat hepatic mitochondria following aflatoxin B1 administration. Toxicol Lett 80(1-3):55-60

Singh BB, Steinnes H (1976) Uptake of trace element by barley in Zinc polluted soil'. Soil Sci 121(1):38-43

Stirpe F, Della Corte E (1969) Regulation of rat liver xanthine oxidase. Conversion in vitro of the enzyme activity from dehydrogenase (type D) to oxidase (type O). J Biol Chem 244(1969):3855-3863

Tietz NW (1982) Fundamentals of clinical chemistry, 2nd edn. W.B. Saunder Co., New York, pp 994-995

Trinder P (1969) Quantitative determination of glucose using the GOD-PAP method. Clin Biochem 6:24-27
Udoh DJ, Iren OB (2016) Evaluation of fish pond effluent as an organic fertilizer in comparison with poultry and pig manures in the cultivation of pineapple (Ananas comosus). IOSR J Agric Vet Sci 9(9):5-10

Udoh DJ, Iren OB, Jonathan JE (2016) Comparison of fish pond wastewater with manures under garden egg in Nigeria. Environ Nat Resour Res 6(3):58-64. https://doi.org/10.5539/enrr.v6n3p58

UNDP (2006). Niger delta human development report, pp 229

Wood CW, Meso MB, Veverica KL, Karanja N (2001) Use of pond effluent for irrigation in an integrated crop/aquaculture system. In: Gupta A, McElwee K, Burke D, Burright J, Cummings X, Egna $\mathrm{H}$ (eds) Eighteenth annualtechnical report. Pond Dynamics/ Aquaculture CRSP. Oregon State University, Corvallis, pp 69-77

Xiao Z, Storms R, Tsang A (2006) A quantitative starch-iodine method for measuring alpha-amylase and glucoamylase activities. Anal Biochem 351(1):146-148. https://doi.org/10.1016/j. ab.2006.01.036

Zhang Y (2013) Ascorbic acid in plants; biosynthesis, regulation and enhancement. Brie Plant Sci 117:8-33

Publisher's Note Springer Nature remains neutral with regard to jurisdictional claims in published maps and institutional affiliations. 